\title{
Yoksulluğun Çocuk Sağlığı Üzerine Çok Boyutlu Etkileri
}

\author{
Dilek KONUK ŞENER ${ }^{1}$, Ayşe Ferda OCAKÇI ${ }^{2}$ \\ ${ }^{I}$ Düzce Üniversitesi Sağllk Yüksekokulu, Düzce, Türkiye \\ ${ }^{2}$ Koç Üniversitesi Hemşirelik Yüksekokulu, İstanbul, Türkiye \\ dilekkonuk@duzce.edu.tr
}

\begin{abstract}
Özet
Dünyada yaşanan gelișmelere karșın yoksulluk çağımızın en önemli sorunu olmaya devam etmektedir. Yoksulluk özellikle gelişmekte olan ülkelerde yaşayan insanları etkilemekle birlikte gelişmiş ülkelerde de karşılaşılan toplumsal sorunlardan birisidir. Günümüzde gelişmekte olan ülkelerde yaşayan çocukların \%40'ı günde bir doların altında gelire sahiptir. Türkiye'de ise on beş yaşından küçük çocukların neredeyse dörtte biri ulusal yoksulluk sınırı altında bulunmaktadır. Sağlık ve yoksulluk arasında, diğer bir deyişle bireyin ve ailelerin sosyo-ekonomik konumları ile sağlık durumları arasında yakın bir ilişki bulunmaktadır. Fizik, sosyal ve biyolojik etkenlerin insan sağlığı üzerindeki etkilerini birbirinden ayırmak olanaksızdır. Bu durumdan etkilenen en duyarlı grup ise çocuklar olmaktadır. Yoksulluk içinde yaşamak çocukların beslenme, hastalık ve kazalardan korunma, sağlıklı yaşama, büyüme ve gelişme açısından gerekli olanaklardan yoksun kalmalarına neden olmaktadır. Yoksul aileler çocuklarına gelişimleri için yeterli olanağ veremedikleri gibi onları erken yaşta çalışmaya zorlamaktadırlar. Çocuklar ya okula hiç gidememekte veya okuldan alını işe verilmektedirler. Düşük gelirli bir ailede yaşamak yetişkin dönemde yoksullukla karşılaşma olasıllığını oldukça yükselttiği için çocuk yoksulluğu acil önlem alınması gereken konular arasında yer almaktadır. Bu nedenle makalede yoksulluk kavramı ile Dünya'da ve Türkiye'de yoksulluk, yoksulluğun çocuk sağllğı üzerindeki önemi ve hemşirelik yaklaşımlarını irdelemek amaçlanmıştır.
\end{abstract}

Anahtar Kelimeler: Yoksulluk, çocuk yoksulluğu, sağlık, hemşirelik

\section{Multi-Dimensional Effects of Poverty on Children Health}

\begin{abstract}
Despite the developments in the world, poverty is still the most important problem of our age. While it affects the people living in the developing countries, it is also one of the social problems encountered in developed countries. Today, $40 \%$ of children in the developing countries have an income less than one dollar per day. In Turkey, almost one fourth of the children under fifteen years old are below poverty line. There is a close relationship between health and poverty; in other words, between socioeconomic status and health conditions of the individual and the families. It is impossible to distinguish the effects of physical, social and biological factors on human health. The most sensitive group that is affected by this condition is children. Living in poverty makes children deprive of necessary amenities for diet, prevention of disease and accidents, healthy living, growth and development. Since poor families can not provide their children adequate opportunities for their development, they force them to work during early ages. Children can never
\end{abstract}


go to school or they were made to leave school and work. Since living within a low-income family highly increases the possibility to face poverty during adulthood, child poverty is included among the issues that need urgent action. Therefore, the purpose of this study was to address the concept of poverty and poverty in Turkey and in the world, the importance of poverty on children health and nursing approaches.

Keywords: Poverty, child poverty, health, nursing

\section{Giriş}

Yoksulluk genelde az gelişmiş ülkelerde karşılaşılan bir sorun olmasına karşın gelişmiş ve gelişmekte olan ülkelerde de görülen ve tarihin her döneminde olduğu gibi günümüzde de birçok ülkenin baş etmek zorunda kaldığ 1 en önemli toplumsal sorunlardan birisidir (Aksan, 2012, Durgun, 2011). Yoksulluk, genel anlamıla, insanların yaşamlarını devam ettirebilmesi için gerekli olan temel gereksinimlerini karşılayamama durumu olarak tanımlanmaktadır. Yoksulluk, insanların sadece gelir, tüketim gibi maddi nesnelerden (gıda, barınma, giyim, vb) yoksun olmalarını değil, aynı zamanda sağlık, eğitim, ulaştırma, sosyal güvence ve toplumsal faaliyetlerdeki hizmetlerden de mahrum olmalarını ifade etmektedir (Arpacıŏlu ve Yıldırım, 2011, Taş ve Özcan, 2012).

Yoksul aileler toplumsal sınıf sıralamasında en alt sırada yer almaktadırlar. Gelir dağılımından, eğitim ve sağlık gibi olanaklardan en az pay alan ailelerdir. İş güvenceleri yoktur ve geleceğe dönük plan yapamamaktadırlar. Bulundukları çevre de diğer yoksul ailelerden oluşmaktadır. Bu ailelerin sağlık koşulları kötü olup, beslenmeleri yetersiz ve dengesizdir. Evleri küçüktür, bir-iki odada tüm aile birlikte yatabilmektedirler. Bu olumsuz koşullar nedeniyle aile bireyleri öfkeli, huzursuz, bezgin ve tükenmişlik içindedir (MEGEP, 2007).

Hem gelişmiş hem de gelişmekte olan ülkelerde yoksulluk sorunundan özellikle yaşlılar, özürlüler, kadınlar ve çocuklar daha fazla etkilenmektedir. Ancak yoksulluk daha ayrıntılı incelendiğinde, en büyük ve önemli etkiyi, çocuklar üzerinde gösterdiği görülmektedir. Ekonomik durumu kötü olan yoksul ailelerde en fazla acıyı çocuklar çekmektedir. Bazı araştırmacılar çocukların geliri olmadığ 1 için "yoksul” sayılamayacağını belirtseler de "çocuk yoksulluğu” günümüzün en üzücü sorununu oluşturmaktadır (Cousins, 2013, Durgun, 2011, Hatun, 2002).

Yoksulluk çocukların hem biyolojik hem de ussal potansiyellerini olumsuz etkilemektedir (Hatun, 2002). Yoksul aileler, çocuklarının yaşama, duygusal, bedensel ve zihinsel gelişme açısından gereksinimlerini karşılayamadıkları gibi onların sömürülmesine, istismarına, şiddet ve ayrımcıllğa uğramasına da neden olmaktadırlar. Çocukların fiziksel, duygusal gelişimlerini sağlayamayan aileler, çocuk yoksulluğunun etkilerinin kuşaklar boyu aktarılmasına neden olmaktadır. Çocuklar bir toplumun geleceğini oluşturmakta bu nedenle her toplum iyi yetişmiş bireyler yaratmak istemektedir. Bunun sağlanamadığı hallerde toplumsal gelişim de olumsuz etkilenmektedir. Bu nedenle çocuklar için en büyük risklerden birisi yoksulluk olmaktadır. Çocuklukta yaşanan yoksulluğun etkileri yaşam boyu sürdüğü için yoksulluk sorunu ve çözüm önerilerine daha fazla önem verilmesi gerektiği düşünülmektedir (Durgun, 2011, UNICEF, 2011). Bu doğrultuda makalede yoksulluk kavramı ile Dünya'da ve Türkiye'de yoksulluğun boyutları anlatılarak, yoksulluğun çocuk sağlığı açısından önemi ve hemşirelik yaklaşımlarını irdelemek amaçlanmıştır.

\section{Yoksulluğun Tanımı}

Değişik dünya görüşlerinin yoksulluk kavramına farklı yaklaşması nedeniyle yoksulluk kavramının tanımlanması oldukça zordur. Yoksulluk kavramı ile ilgili yazın diziliminde farklı görüşler yer alsa da, kavram ve çeşitleri açısından bazı ortak noktalara rastlamak olasıdır. Yoksulluk en genel ifade ile bireylerin yaşamını normal koşullarda devam ettirebilmesi için gereksinimleri olan 
kaynaklara yeterli ölçüde sahip olamaması anlamına gelmektedir (Aksan, 2012, Arpacıoğlu ve Y1ldirım, 2011).

Çoğu insan yoksulluğu, açlık, yetersiz beslenme, barınma olanağının olmaması, eskimiş ya da yıpranmış giyim, temizlenemeyen beden, temiz içme suyuna ulaşamama, temel eğitim ve sağlık hizmetlerine erişememe biçiminde kabul etmektedir. Bu açık düşünce birliğine karşın, yoksulluğu tanımlamaya yönelik açık ve nesnel bir yol bulunmamaktadır (Temiz, 2008).

Küresel ölçekte yoksulluk değerlendirilirken Dünya Bankası, kişi başına günlük bir dolar kazanc1 "uluslararası yoksulluk sınırı" olarak kabul etmekte ve bu sınıra göre belirlediği yoksulluğu "gelir yoksulluğu" olarak tanımlamaktadır. Beslenme için gerekli en az kalori ve temel gereksinimlerin karşılanamaması "temel gereksinim yoksulluğu", bütün gelirin besin için harcandığ 1 ve buna karşın yeterli besinin sağlanamadığı durum ise "ağır yoksulluk" olarak ifade edilmektedir. Bu düzeydeki bir yoksulluk açılımı genellikle az gelişmiş ülkeler için kullanılmaktadır. Bu nedenle günlük bir dolar biçimindeki ölçütlere dayandırılmış tanıma karşı önemli eleştiriler getirilmektedir (Begum, Deng and Gustafsson, 2012, Hatun, 2002, Temiz, 2008).

\section{Dünyada ve Türkiye'de Yoksulluğun Boyutları}

Yoksulluk, bir ülkenin gelişmişlik düzeyi ile yakından ilişkilidir. Genel olarak, az gelişmiş ülkelerde yoksulluk oranı nüfusun $\% 40$ ile $\% 80$ 'i arasında değişmekte, gelişmekte olan ülkelerde ise \%40'ın altına düşmektedir. Ekonomik ya da sosyal boyutlu gelişmelere paralel olarak ortaya çıkan yoksulluk olgusu, gelişmiş ülkelerde dahi karşımıza çıkmaktadır. En zengin ülkelerde yaşayan nüfusun \%12'sini yoksullar oluşturmaktadır (Arpacıoğlu ve Yıldırım, 2011).

Dünya'da bir milyardan fazla insan aşırı yoksulluk (günlük bir doların altında bir gelir) içerisinde yaşamaktadır. Her yıl yaklaşık olarak on sekiz milyon insan yoksulluğa bağlı nedenlerden çok erken yaşta hayatlarını kaybetmektedir. Bu rakam toplam insan ölümlerinin üçte birine eşittir. Her gün otuz dört bini beş yaşın altında çocuklar olmak üzere toplam elli bin insan yoksulluğa bağlı nedenlerle ölmektedir (Kabaş, 2009).

Dünyada çocuk yoksulluğu oranlarına bakıldığında Danimarka, Finlandiya, Norveç ve İsveç gibi gelişmiş ülkelerde bile çocukların en az \%6'sının yoksul bölgelerde yaşadığı bilinmektedir. Avusturya, Hollanda ve İsviçre'de çocukların \%7-9'u yoksulluk içinde yaşamaktadır. Çek Cumhuriyeti, Almanya, Avustralya, Lüksemburg ve Birleşik Krallık'da \%10-15, İrlanda, Kanada ve Polonya'da \%16-20, Amerika Birleşik Devletleri'nde (ABD) \%21, Guatemala ve Brezilya'da \%3032 oranında yoksul çocuk bulunmaktadır (Gornick and Jäntt, 2012).

Uluslararası karşılaştırmalarda, yoksulluk göstergeleri bakımından pek parlak bir durumda olmayan Türkiye, gelirin son derece adaletsiz olarak dağıldığı ülkeler arasında yer almaktadır. Yoksulluk, Türkiye gibi gelişmekte olan bir ülkede en önemli sorunlardan biri haline gelmiştir. Gelir düzeyi ve tüketim harcamaları temelinde daha kapsamlı biçimde ölçüldüğünde önemli eşitsizliklere işaret etmektedir. Bir yandan adaletsiz gelir dağılımı, diğer taraftan ulusal gelirin paylaşımındaki düşüklük, son yıllarda yaşanan ekonomik krizler, başarısız politikalar yoksulluğu daha da şiddetli bir boyuta taşırken, acil önlem alınması gereken bir duruma gelinmiştir. Yoksulluk oranlarına bakıldığında, nüfusun altıda biri ülke ölçeğinde belirlenen yoksulluk sınırının altındadır. Kırsal nüfusun ise üçte biri bu sınırın altında bulunmaktadır (Arpacıoğlu ve Yıldırım, 2011, UNICEF, 2011).

Türkiye'de yoksul yaşayan çocuk oranı, aynı durumdaki yetişkinlerin oranından daha yüksektir. On beş yaşından küçük çocukların neredeyse dörtte biri ulusal yoksulluk sınırı altındadır. Kırsal kesimde ise bu oran beşte ikinin üzerindedir. Düşük gelir gruplarında kalabalık aileler genellikle yaygındır ve bu ailelerdeki çocuklar, kimi bölgeler söz konusu olduğunda, yoksulluğa özellikle açık durumda bulunmaktadır (UNICEF, 2011). 


\section{Çocukların Yoksul Olmasının Nedenleri}

Çocukların yoksulluğu, ailelerinin yoksulluğuna bağlı olmaktadır. Bir çocuğun birlikte yaşadığı ailesinin kişi başına harcanabilir geliri belirlenen yoksulluk sınırının altında ise o çocuk yoksul olarak kabul edilmektedir. Bu durumun en önemli nedeni ebeveynlerin eğitim düzeylerinin düşük olması, iş bulamaması veya düzensiz işlerde çalışmak zorunda kalmasıdır (Begum, Deng and Gustafsson, 2012, Curtis, Voss and Long, 2012, Fotso et al., 2012, Gornick and Jäntti, 2012, Hatun, 2002, Joo, 2013, Trani and Cannings, 2013). Curtis, Voss ve Long (2012) ile Joo'nun (2013) göçmen aileler ile yapmış olduğu çalışmada ebeveynlerin eğitim yetersizliği ve iş olanaklarının sınırlı olmasının, yoksulluğun en büyük nedeni olduğu belirlenmiştir. Bu durumun eğitim düzeyi düşük ebeveynlerin kolay iş bulamaması, iş buldukları zaman ise düşük beceri gerektiren, düşük ücretli işlerde çalışmalarından kaynaklandığı düşünülmüştür.

Çocukların aile yapısı da yoksulluğa sürüklenmelerinde risk oluşturmaktadır. Kalabalık ailelerde yoksulluğun görülme oranı daha fazladır. Begum, Deng ve Gustafsson'un (2012) yaptıkları çalışmada çocuk yoksulluğu oranının en fazla çok çocuklu ailelerde görüldüğü belirlenmiştir. Ayrıca, annebabası boşanmış çocuklarda riskli grupta bulunmaktadır. Yapılan çalışmalarda bu çocuklarda da yoksulluğun görülme oranının daha fazla olduğu belirlenmiştir (Anthony King and Austin, 2011, Begum, Deng and Gustafsson, 2012, Gornick and Jäntti, 2012). Anne ile yaşayan çocukların, baba ile yaşayan çocuklardan daha yoksul oldukları ve daha kötü koşullarda yaşadığı da bilinmektedir (Curtis, Voss ve Long 2012).

Çocuk yoksulluğunun en büyük nedenlerinden biri de savaş ve yapılan zorunlu göçlerdir. Yoksulluk ve savaşlar arasında güçlü bir bağ bulunmaktadır. Savaş bir ülkenin ekonomik sistemini ve temel hizmetlerini derinden etkilemektedir. Sonuçta geçim olanakları sinırlanan halk yoksulluğa sürüklenmektedir. Ayrıca aile bireyleri savaş yüzünden yer değiştirme ve göçe zorlandığı için ciddi ekonomik ve sağlık sorunları yaşanmaktadır. $\mathrm{Bu}$ aileler zorunlu göç yüzünden evlerini geride bırakmak zorunda kaldıkları için mal varlıklarını kaybetmektedirler. Yeterli sağlık hizmetlerinin verilememesi ve sık sık travmatik olay yaşama ise hastalık, sakatlık ve ölüm oranlarını artırmaktadır (Trani and Cannings, 2013).

\section{Yoksulluğun Çocuk Sağlığı Üzerindeki Etkisi}

Çocuklar ve ergenler hangi toplumda olursa olsun yoksulluğun olumsuz etkilerine en açık, en korunmasız durumda olan üyeleridir. UNICEF, "Dünya Çocuklarının Durumu 2005" raporunda yoksulluk içinde yaşayan çocuklara ilişkin şöyle bir tanımlama yapılmaktadır. "Yoksulluk içinde yaşayan çocuklar, yaşama, büyüme ve gelişmeleri açısından gerekli maddi, manevi ve duygusal kaynaklardan yoksun biçimde yaşamakta, böylece haklarından yararlanamamakta, yeteneklerini tam olarak geliştirememekte ve topluma tam ve eşit üyeler olarak katılamamaktadırlar”. Çocuklar yoksulluğu daha derinden hissettiği için yoksulluktan ve eşitsizliklerden en fazla etkilenenler de onlar olmaktadır (Durgun, 2011, UNICEF, 2005, 2012).

Gereksinimi yüksek olan çocuklar aynı zamanda hakları en fazla ihlale uğrayan çocuklardır. Yoksulluk, büyümekte olan çocuklar için özellikle zararlı olabilmektedir. Yoksulluk yüzünden kötü beslenme ve hastalık durumları ortaya çıkabilir, eğitim yarıda kesilebilir ve çocuklar şiddetin, sömürünün ve ihmalin tüm biçimlerine maruz kalabilirler. Yoksul çocukların ileride yoksul yetişkinler olma olasılığı oldukça yüksek bulunmaktadır. UNICEF, çocuk yoksulluğunun göstergesi olarak, bebek ve çocuk ölüm oranlarını, beş yaş altındaki düşük ağırlıklı veya kısa boylu çocuk oranını, temiz içme suyuna ulaşan nüfus oranını, yeterli temizlik ve sağlık bakımını, tam aşılı çocuk oranı ve ilköğretime başlayan çocuk oranını kabul etmektedir (Hatun 2002, UNICEF, 2011, 2012). Şekil 1'de yoksulluğun çocuk sağlığı üzerindeki etkileri şematize edilerek gösterilmektedir (Fajth, Engilbertsdóttir and Kurukulasuriya, 2012). 


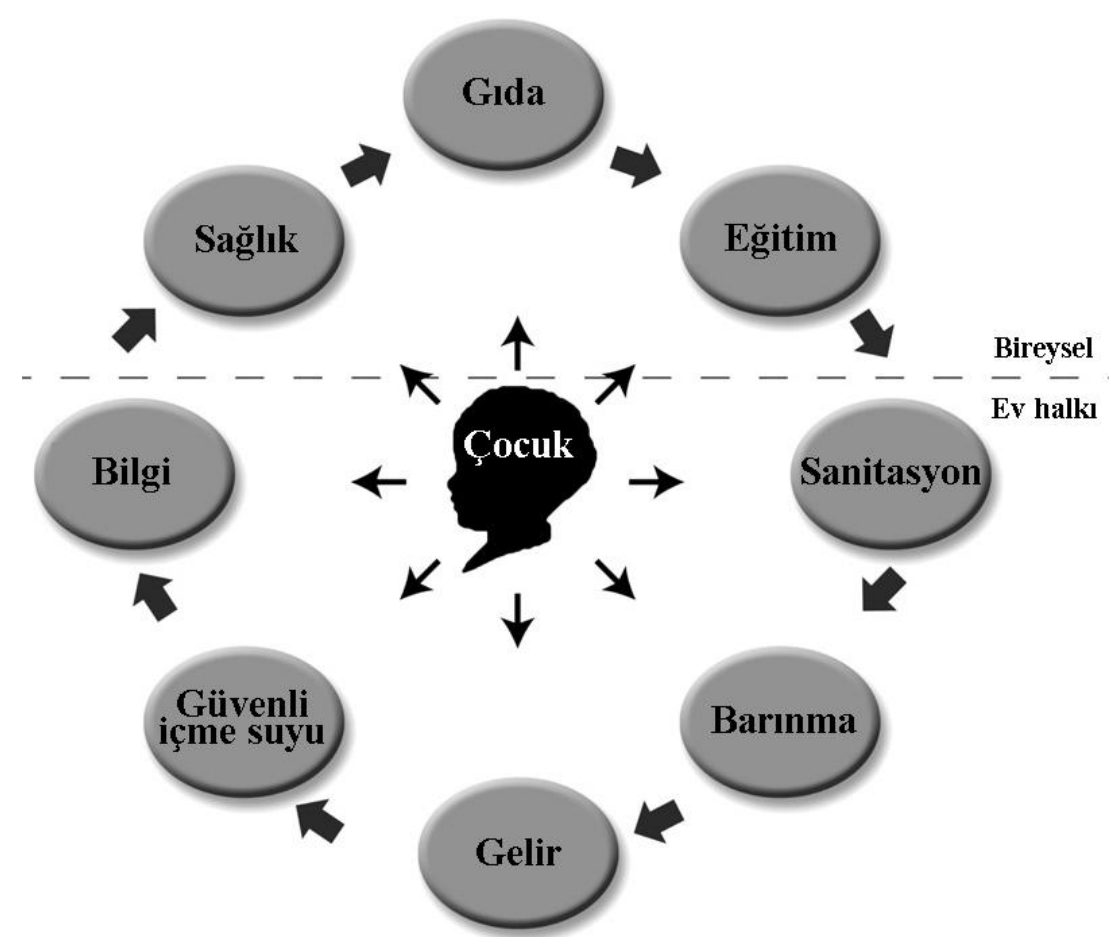

Şekil 1. Çocuk Yoksulluğunun Sekiz Farklı Alandaki Etkileri

Yoksulluğun çocuklar üzerindeki en bilinen ve en sık görülen etkisi beslenme yetersizliğidir. Yoksulluk, eve giren besinlerin yetersizliğine, ev içi stres ve annenin kronik yorgunluğu nedeniyle anne sütünün erken kesilmesine, annenin beslenme yetersizliğine ve bebeklerin düşük doğum ağırlıklı olmasına neden olarak çocuklardaki beslenme yetersizliğinin temel belirleyicisi olarak rol oynamaktadır. Yetersiz beslenme, tüm dünyada beş yaşından küçük çocuk ölümlerinin üçte birinden fazlasına neden olabilmektedir. Ayrıca yeterli miktarda meyve, sebze, balık veya etten alınan A vitamini, demir veya çinko gibi temel besleyici maddeler alınmadığı zaman çocuklarda ölüm, körlük, bodurluk, motor ve bilișsel gelișimde gerilik ve IQ düşüklüğü görülebilmektedir. Türkiye'de beș yaşından küçük olup bodurluğa maruz çocuk oranı 1998'de \%16.0, 2003'te \%12.2 ve 2008 'de \%10.3 olarak belirlenmiştir. Yurtdışında yapılan çalışmalarda da yoksulluğa bağlı beslenme yetersizliği ile çocuklarda bodurluk görülmesi arasında güçlü bir ilişki olduğu bulunmuştur. Hackett ve arkadaşlarının (2009) Kolombiya'da, Bisai ve arkadaşlarının (2010) Hindistan'da yaptıkları çalışmada yoksul çocukların bodurluk risk oranı sırasıyla \%42.1 ve \%52.7 olarak tespit edilmiştir. Fotso ve arkadaşlarının (2012) Kenya'da yaptıkları çalışmada yoksul ailelerde yaşayan çocuklarda bodurluk görülme oranı yaşamın ilk üç ayında \%9 olarak belirlenmiş, bu oranın sürekli artarak çocuklar 15-17 aylık olduklarında \%60'a ulaştığı ve bu korkunç tablonun daha sonraki yıllarda da sabit kaldığ1 görülmüştür (Anthony, King and Austin, 2011, Bisai, Ghosh and Bose, 2010, Fotso et al., 2012, Hackett, Melgar-Quiñonez and Álvarez, 2009, Hatun, 2002, Isanaka et al., 2007, TNSA, 2008, UNICEF, 2012).

Yoksulluk ve beslenme yetersizliği bedensel ve zihinsel gelişimi olumsuz etkilediği için engelliler, gelişme geriliği olanlar ve kronik hastalıklara yakalananlar daha çok yoksul çocuklardır (Anthony King and Austin, 2011, Durgun, 2011, UNICEF, 2011). Ersoy (2006) ile Trani ve Cannings'in (2013) yapmış oldukları çalışmada engelli çocuklar arasındaki yoksulluk görülme sıklığının daha yüksek olduğu belirlenmiştir. Ersoy'un (2006) yaptığı aynı çalışmada 0-5 yaş arasındaki çocukların Diyarbakır örnekleminde \%22'sinin, Ankara'da ise \%10'unun sürekli hastalığa sahip olduğu görülmüştür. Yapılan diğer çalışmalarda da yoksul ailelerin çocuklarında Tip II Diabet, 
obezite ve hipertansiyon gibi kronik hastalıkların daha fazla görüldügü belirlenmiştir (Anthony King and Austin, 2011, Phipps et al., 2006).

Yeterli ve dengeli beslenme kadar güvenli ve sağlam bir konut da çocukların temel ihtiyacıdır. Yalnız beslenme yetersizliğine ek olarak yoksul çocukların karşılaştıkları güçlükler arasında yer alan elverişsiz konutlarda ve kalabalık ortamda yaşama, su ve sanitasyon olanaklarına yetersiz erişim ve yetersiz korunma nedeniyle çocukların sağlıkları olumsuz etkilenmektedir. Yoksul çocukların bazıları kalacak ev bile bulamayarak sokakta yaşam mücadelesi vermektedir. Yetersiz yaşam koşulları, çocuk haklarının en yaygın ihlalleri arasındadır. İnsana yakışır ve güvenli konut, su ve sanitasyon sistemleri gibi altyapı olmadan bu çocukların yaşamaları, büyüyüp gelişmeleri oldukça zordur. Sağlıksız ve kirli bir ortamda sağlığ sürdürmek mümkün olmadığ için temiz olmayan içme suyu, yetersiz sanitasyon ve hijyenik olmayan koşullar yüzünden her yıl çok sayıda insan ölmektedir ve bunların çoğunluğunu beş yaş altı çocuklar oluşturmaktadır. Hijyenik olmayan bir çevre bağırsak enfeksiyonları ve hepatit başta olmak üzere birçok hastalığın sorumlusudur. Dünyada her gün beş yaşından küçük tahminen iki bin çocuk ishalli hastalıklar yüzünden ölmekte bu ölümlerin yaklaşık bin sekiz yüzü temiz olmayan su, sanitasyon ve hijyenle ilişkili olmaktadır. Türkiye'de TNSA 2008 verilerine göre beş yaş altı çocukların \%23'ünün araştırmadan önceki iki hafta içinde ishale yakalandığı belirlenmiştir. Türker ve arkadaşlarının 2008-2010 yılları arasında yaptıkları çalışmada 0-14 yaş grubunda Hepatit A görülme sıklığ yaklaşık \%27 olarak bulunmuştur (Anthony King and Austin, 2011, Temiz, 2002, UNICEF, 2011, 2012).

Yetersiz yaşam koşulları nedeni ile çocukluk döneminde görülen solunum yolu hastalıkları da yoksullukla beraber artış göstermektedir. Yoksulluğun en acılı sonucu bu önlenebilir hastalıklara karşın bebek ve çocuk ölümlerinin fazla olmasıdır. Eldeki veriler çocukların savunmasızlığını ortaya koymaktadır. 2010 yılında dünyada beş yaşına gelmeden çoğu pnömoni, ishal veya doğum komplikasyonları gibi nedenlerden dolayı ölen çocuk sayısı yaklaşık olarak sekiz milyondur. İç mekânlardaki hava kirliliği beş yaşından küçük çocuklar arasında her yıl dünyada iki milyon kadar ölüme neden olmaktadır. Yoksul ailelerin iyi havalandırılmayan mekânlarda yemek pişirme amacıyla zararlı yakıtlar kullanması da hava kirliliği sorununa katkıda bulunan etmenler arasında bulunmaktadır (Cousins, 2013, Durgun, 2011, Hatun, 2002, UNICEF, 2012).

Yoksul çocukların güvensiz ev ortamında yaşamaları nedeniyle bekleyen bir diğer tehlike ise ev kazalarıdır. Bu çocukların anne-babaları yeterli bakım ve desteği sağlayamadıkları için çocuklar kazalara açık hale gelmektedir. Ebeveynler kazaların çocuk sağlığı üzerinde ciddi sorunlara yol açabileceğinin farkında olamadıkları için, evde kazalardan korunmak için gerekli düzenlemeleri yerine getirememektedirler. Ayrıca yoksul çocuklar ev kazalarını önleme programlarından ve kaliteli sağlık hizmetlerinden yararlanamadıkları için ev kazaları açısından daha fazla risk altında bulunmaktadırlar (Alasya, 2012, Hjern, Ringback and Andersson, 2001, Turan ve Ceylan, 2007). Yapılan çalışmalarda da yoksul ailelerde yaşayan çocukların daha fazla ev kazası geçirdiği belirlenmiştir. Şahiner ve arkadaşlarının sosyo-ekonomik düzeyi düşük ailelerle yaptıkları çalışmada 0-4 yaş grubu çocuklar arasında ev kazası görülme sıklığ1 \%17.9 olarak belirlenmiştir. Turan ve Ceylan'ın yaptıkları çalışmada ise 0-6 yaş çocuğu olan annelerin çocuklarının son bir ay içinde \%19.3'ünün ev kazası geçirdiği bulunmuştur. Alasya'nın yaptığ az bir kez ev kazası geçirdiği belirlenmiştir.

Yoksulluğun ve açlı̆̆ın biyolojik etkileri kadar psikososyal ve davranışsal etkileri de önemlidir ve bu konuda geniş bir yazın dizilimi bulunmaktadır. Yoksul ailelerin çocuklarının psikososyal gelişimleri geri kalmakta ve duygusal, düşünsel ve davranışsal sağlık sorunları daha fazla görülmektedir. Yapılan çalışmalarda bu çocuklarda "öğrenme güçlüğü" "anksiyete" "depresyon" "intihar" ve "hiperaktivite" riskinin arttı̆̆ saptanmıştır. Yoksul çocukların algılama fonksiyonlarındaki düşme ve öğrenme kapasitelerindeki azalma nedeniyle okul başarılarının düşük olduğu gözlenmektedir. Ayrıca zekâ gerilikleri, dikkat ve özgüven eksikliği, uyarıcı ya da uyuşturucu 
madde kullanımı, ailede boşanma veya alkolizm gibi çatışmalar da başarısızlık nedeni olabilmektedir. Çocuklardaki bu sorunların kaynağının ise stres olduğu düşünülmektedir. Yoksulluk ve buna bağlı yetersiz yaşam koşulları ile ailelerinden yeterince sevgi ve ilgi görmemeleri stres hormonlarının düzeyini değiştirerek çocukların gelişimini olumsuz etkilemektedir (Anthony King and Austin, 2011, Blair et al., 2013, Drake and Rank, 2009, Fotso et al., 2012, Hannum, Liu and Frongillo, 2014, Hatun, 2002, Trani and Cannings, 2013).

Yeterli beslenemeyen ve özellikle erken çocukluk döneminde yeterli uyarımlar alamayan çocuklar tam potansiyellerini gerçekleştirememektedirler. Derslerine odaklanma sorunu yaşamakta ve akademik görevlerini yerine getirememektedirler. Yoksul çocukların kaliteli bakım alma veya okul öncesi eğitime katılma şansları da daha azdır. Ayrıca bu çocuklar okula erişimde, okul malzemelerini satın almada veya ders çalışacak yer bulmada da güçlüklerle karşılaşabilmektedirler. Hem bu nedenler hem de davranış sorunları ve sık hastalanma nedeniyle okula gidemeyen yoksul çocuklar arasında okul başarısında düşme, okul idaresi tarafından cezalandırılma ve okulu bırakma oranı yüksek olmaktadır (Anthony King and Austin, 2011, Drake and Rank, 2009, Fotso et al., 2012, Hannum, Liu and Frongillo, 2014, Hatun, 2002, UNICEF, 2011).

Çocuk yoksulluğunun bir diğer önemli boyutu ise çocuk işçiliğidir (Temiz 2008). Sokaklarda yaşayan ve çalışan çocuklar, çeşitli amaçlarla kaçırılıp satılanlar ve çocuk yaşlarda işçi olarak çalışanlar için hedefleri net olarak belirlenmiş çözüm yolları bulunmalıdır. Sokaklarda çalışma ve mevsimlik tarım işçiliği gibi çocuk işçiliğinin en kötü biçimleri ülkemizde halen sürmektedir. $\mathrm{Bu}$ işlerde çalışan çocuklar okullarından geri kalırlar, boş zaman ve toplumsallaşma olanağı bulamazlar. Söz konusu çocukların gelecekleri de tehlikelidir. Çocuklar kötü beslenmeden hastalıklara, kazalara, şiddet eğilimlerine, sokak yaşamına veya suça karışmaya kadar uzanan çeşitli risklerle karşılaşmaktadır (UNICEF, 2011, 2012).

Çocuk işçiliğinin nedenleri arasında yoksulluğa ek olarak sosyoekonomik ve kültürel etmenlerle birlikte yasa ve denetimlerdeki boşluklar da yer almaktadır. Yoksul ailelerde çocuklara ilgi yetersiz olduğu için bu çocuklara erken yaşlarda sorumluluk ve bağımsızlık verilerek evin geçimine bir şekilde katkıları beklenmektedir. Yoksul insan için kendi vücudu sermayesidir. Çocukluğu da bir sermaye olarak görmektedir. Geliri düşük olmasına karşın aile gereksinim duyduğu için çocuktan çalışmasını bekler. Eğitim için ise zaman çok uzun gelir. Bu durumda çocuk çoğunlukla sokakta ve denetimsiz kalarak sokağın tüm olumsuz etkileri ile karşılaşır. Maddi ve manevi yoksunluğun bilincine vardığında ise bu duruma tepki göstererek suça itilmeleri ve riskli davranışlara yönelmeleri daha kolay olur (Durgun, 2011, MEGEP, 2007, UNICEF, 2011, Zuberi, 2012).

Yoksul ailelerde yaşayan çocukların kendi evlerindeki temel gereksinimler kadar önemli bir diğer konu ise kendilerine olumlu rol modelleri bulamamaları ve suçlu bir çevre içinde yaşamak zorunda kalmalarıdır. Yoksul çocukların bu çevre içinde yaşayan çocuk ve aileler ile riskli ilişkiler içinde olmaları onların da riskli davranışlara yönelmelerine neden olmaktadır (Zuberi, 2012). Taşçı ve arkadaşlarının (2005) yaptıkları çalışmada öğrencilerin \%31.4'ünün sigara, \%31.4'ünün alkol ve \%15.7'sinin madde kullandıkları belirlenmiştir. Görgün, Tiryaki ve Topbaş'ın (2010) yaptıkları çalışmada ise katılımcıların yaşam boyu bir kez madde kullanım yaygınlığ $\% 5.6$ olarak saptanmıştır. Yapılan diğer çalışmalarda da yoksul ailelerin çocuklarında adölesan gebelik, suç işleme ve şiddet oranlarının daha fazla olduğu belirlenmiştir (Anthony, King and Austin, 2011, Drake and Rank, 2009, Sampson, Morenoff and Gannon-Rowley, 2002).

Şiddetin arkasındaki nedenler çok sayıda ve karmaşıktır. Ancak, yoksulluk ve eşitsizlik bunlar arasında başta gelmektedir. Yoksul çocuklar suç ve şiddet karşısında savunmasız kalmaktadırlar. Şiddet karşısında çocukların kimileri hedef, kimileri de katılımcı veya tanık durumundadır. Yapılan çeşitli çalışmalarda yoksul mahallelerde yaşayan çocukların yüksek derecede şiddet yaşadıkları veya yaşanan şiddete tanık oldukları belirlenmiştir (Aneshensel and Sucoff, 1996, Bowen and Bowen, 
1999, Zuberi, 2012). Şiddetin hüküm sürdüğü ortamlara küçük yaşlarda tanıklık etmek çocukların yetişkinlere ve toplumsal düzene olan güvenini sarsmakta, gelişimlerini olumsuz etkilemektedir. Özellikle aile içi şiddete maruz kalan çocuklar okullarında başarısız olmakta ve bu çocuklar arasında okulu bırakma yaygın olarak görülmektedir. Ayrıca anksiyete, depresyon, saldırganlık ve kendini denetleyememe gibi sorunlar baş göstermektedir (UNICEF, 2012).

Aile içi şiddet ile ilgili yapılan çalışmalara bakıldığında, Sucaklı (2003) çocuğa yönelik aile içi şiddet oranını \%70.4 olarak belirlemiştir. Aynı çalışmada çocukların \%29'unun ailede sadece anne, \%4.6'sının ailede sadece baba ve \%37.1'inin ise ailede hem anne hem de baba tarafindan fiziksel şiddete maruz kaldıkları tespit edilmiştir. Bayındır'ın (2010) Kütahya'da yaptığı çalışmada ise çocukların \%68.2'sinin aile içinde yaşanan şiddete tanık olduğu ve bu çocukların \%20.5'inin şiddet durumunda şiddete uğradığ 1 belirlenmiştir. Ayrıca annelerin \%60.2'si çocuklarının bu durumdan olumsuz etkilendiklerini belirtmişlerdir. Duman, Özdağ ve Özcan'ın (2003) hemşirelik öğrencilerinin şiddete yönelik duygu ve davranışlarını belirlemek amacıyla yaptıkları çalışmada, öğrenciler dayak yeme karşısında çocuğun öfke duyacağı ve şiddet eğiliminin artacağı (\%53.3), aşağılanma karşısında benlik saygısında azalma olacağ 1 (\%76.5), anne-baba arasındaki şiddete tanık olma durumunda babaya öfke duyacağı (\%63.5), çocuğa güvenilmemesinin karşısında da güven duygusunda azalma olacağı (\%59.1) şeklinde görüşlerini belirtmişlerdir.

\section{Yoksulluğun Çocuk Sağlığı Üzerindeki Etkisini Önlemede Hemşirenin Rolü}

Amacı toplumdaki bireylerin sağlığını korumak ve geliştirmek, sağlığın bozulduğu durumlarda ise iyileştirmek olan hemşirenin yoksul çocukların bakım ve sağlığının sürdürülmesinde de önemli rol ve sorumlulukları vardır. Hemşireler, gerek koruyucu, gerekse tedavi edici hizmetlerde sürekli olarak çocuk ve aile ile birlikte oldukları için bu konuda da önemli görevler üstlenirler (Akça-Ay, 2008).

Günümüzde hastalıkların tedavisinden çok, sağlığın korunması ve geliştirilmesine ağırlık verilmektedir. Yoksulluğa bağlı görülen çocukluk dönemindeki sağlık sorunlarının birçoğu önlenebilmektedir. Bu nedenle hemşirelerin koruyucu sağlık hizmetlerinde sağlığ geliştirici işlevleri oldukça önem kazanır. Yoksul ailelerin genellikle eğitim düzeyleri düşük olduğu için, çocuk ve aile ile iyi ilişkiler kurulup, gözlem ve görüşmeler yapılarak onlara gereksinimleri doğrultusunda eğitim ve danışmanlık hizmetlerinde yardımcı olunmalıdır. Özellikle hemşirelerin, beslenme, bağışıklama, sık görülen çocukluk dönemi hastalıkları ve ev kazaları konularında aileleri eğitmeleri ile birçok hastalık ve ölümlerin önlenmesi olasıdır (Gürarslan, Baş ve Karataş, 2013, Törüner ve Büyükgönenç, 2012).

Ev kazaları çocuğun sağlığı üzerinde fiziksel, psikolojik ve sosyal yönden olumsuz etki ederek hastalık, sakatlık ve ölümlere neden olabilmektedir. Ev kazaları ev içerisinde yapılacak basit düzenlemeler ve çocuklarla en çok zamanını geçiren annelere düzenli olarak verilecek eğitimlerle ebeveynlerin bilinçlenmesi sağlanarak önlenebilir. Yapılan çalışmalarda ebeveynlere yapılan hemşirelik girişimleri ile ev kazalarının görülme sıklığının azaldığ 1 belirlenmiştir (Altundağ, 2005, Çınar-Dede, 1999, Turan ve ark., 2010).

Yoksulluğa bağlı olarak görülen olumsuz çevre koşulları çocuk sağlığını ciddi biçimde tehdit ederek, bebek ve çocuk ölümlerine neden olmaktadır. Ev hijyeni, aile hijyeni, yeterli ve güvenilir su bulunmaması, atıklar ve benzeri faktörler bulaşıcı hastalıklara sebep olarak çocuk sağlığını tehdit etmektedir. Bu tür hastalıkların önlenmesi konusunda ailelere verilen eğitim ve danışmanlık ile toplum ve kurumlardan alınan sosyal destek de çocukların sağlık durumunun geliştirilmesi ve sürdürülmesinde gerekli olmaktadır (Özcebe, 2006, Törüner ve Büyükgönenç, 2012).

Aile içi etkileşimin ve diğer sosyal etkileşimlerin sağlıklı olması çocuğun psikolojik ve entelektüel gelişimde önem taşımaktadır. Fakat yoksul çocuklar ailelerinden yeterli duygusal ilgiyi göremedikleri için psikososyal gelişimleri geri kalmakta, çeşitli duygusal, düşünsel ve davranışsal sağlık sorunları görülmektedir. Hemşire, ergenlerin duygusal, düşünsel ve davranışsal sağlığını 
değerlendirip, riskli aileleri belirleyerek bozuklukların önlenmesi için girişimlerde bulunmalıdır. Herhangi bir bozukluğun tespit edilmesi durumunda ise tedavi için planlamalar yapıp, tedavinin etkinliğini değerlendirerek gerekirse aileleri ilgili sağlık kurumlarına yönlendirmelidir (Ball, Bindler and Cowen, 2010, Törüner ve Büyükgönenç, 2012).

Ailelerinden yeterli duygusal desteği göremeyen yoksul çocuk ve gençleri bekleyen bir diğer tehlike, bu çocukların duygusal ve sosyal bir boșluk yaşayarak sigara, alkol ve madde kullanımına yönelmeleridir. Çocuk ve ergenler arasında önemli bir sorun olan madde bağımlılığının önlenmesinde hemşirelere önemli görev ve sorumluluklar düşmektedir. Bu konuda hemşirelerin rolü madde bağımlılığının zararları konusunda eğitim, olumlu çevrenin sağlanması ve riskli gruplara yönelik müdahaleleri başlatmayı içermelidir. Risk grubundaki yoksul çocuklar aileleriyle birlikte ele alınarak danışmanlık hizmetleri sunulmalıdır. Ayrıca konuya ilişkin epidemiyolojik çalışmalar artırılarak, okul hemşireleri, rehberlik uzmanları, sosyal çalışmacılar ile multidisipliner işbirliği sağlanmalıdır (Kaya ve Şahin, 2013, Koyun, Taşkın ve Terzioğlu, 2011).

Yoksul çocukların maddi kaynaklara sahip olamaması farklı yoksunlukları da beraberinde getirmektedir. $\mathrm{Bu}$ çocuklar toplumda eğitim, sağllk gibi türlü hizmetlerden de yeterince faydalanamamaktadırlar. Aynı zamanda toplumdaki diğer çocuk ve gençlerle aralarındaki farklar dolayısıyla "farklı" görülüp çeşitli alanlarda dışlanmaktadırlar. $\mathrm{Bu}$ durum ise söz konusu yoksunlukların daha şiddetli yaşanmasına sebep olabilecek problemlere kapı aralamaktadır Hemşire, bu durumdaki çocukları belirleyerek onları savunma rolünü de üstlenmelidir (Aksan, 2012, Törüner ve Büyükgönenç, 2012).

Şiddet olgusu, hem dünyada hem de ülkemizde toplum birliğini bozan ciddi bir sorun haline gelmiştir. Son dönemde dünyanın çeşitli yerlerinde yapılan araştırmalar, özellikle yoksul çocuklar olmak üzere hemen hemen bütün çocukların evlerinde, okullarında ve içinde yaşadıkları toplumda şiddete tanık, hedef veya katılımcı olduklarını göstermektedir. Şiddet davranışı gerçekleştiren bireylerin, şiddet davranışını sergilemeyenlere göre daha çok aile içi şiddete maruz kaldıkları veya daha çok şiddet davranışının sergilendiği ortamlarda büyüdükleri görülmektedir. Bu çerçevede aile içi şiddetin varlığ 1 , gelecekteki şiddet davranışının güçlü bir göstergesi olmaktadır (Bayındır, 2010, Duman, Özdağ ve Özcan, 2003, UNICEF, 2011, Y1lmaz, 2012).

Toplum için bu kadar önemli bir sorun olan aile içi şiddetin ortaya çıkarılmasında ve azaltılmasında hemşirelere büyük görevler düşmektedir. Özellikle koruyucu sağlık hizmetlerinde aileyi doğrudan gözleyebilme ve etkileyebilme şansına sahip olan hemşire grubu aile içi şiddeti ele almak için önemli fursatlara sahiptir. Anne babaların sürekli eğitilmeleri, bilinç ve duyarlılık geliştirme çalışmaları ailede şiddetin azaltılmasında önemli bir rol oynayabilmektedir (Bayındır, 2010, Duman, Özdağ ve Özcan, 2003, Yılmaz, 2012).

\section{Sonuç}

Çocuk yoksulluğu faaliyetlere, hizmetlere ve firsatlara erişimin sınırlandırılmasıyla çocukluk yaşantısına zarar vermekte, risklerle karşı karşıya kalmayı artırmakta ve kaynaklara erişimi azaltarak zorlukları arttırmaktadır. Anne babaları bu çocuklara yeterli bakımı ve desteği sağlayamamakta, bu yüzden çocuklar kazalara, suiistimale, sokak yaşamına veya suça daha açık hale gelmektedir (Temiz, 2002, UNICEF, 2011).

Yoksulluğa bağlı olarak görülen beslenme yetersizliği, hastalıklar, eğitim olanaklarının sınırlılı̆̆ ve duygusal yoksunluk geri dönüşümü olmayan sonuçlar doğurabilmektedir (Trani and Cannings, 2013). Yoksulluk içinde yaşayan çocukların büyük bir kısmının güvenli yaşam alanları olmadığı gibi sıklıkla kalabalık ve yetersiz barınma koşulları altında yaşadıkları da bilinmektedir. Bu nedenle yoğun 
yoksulluk ve hizmet yetersizliği bebek ve çocuk ölümlerini artırmaktadır (Temiz, 2002, UNICEF, 2012).

Çocuk yoksulluğunun önemli bir diğer boyutu da yetişkin yaşamındaki firsat eşitliğini esirgemesidir. Yoksulluk içinde büyüyen çocukların karşılaştıkları sorunlar, özellikle de eğitim alanındakiler, yetişkinlik dönemine yeterince hazırlanamamalarına yol açmaktadır. $\mathrm{Bu}$ çocuklar yetişkin olduklarında düzenli iş bulamamakta, kamu hizmetleri almak veya çocuklarına yeterince bakmak için gerekli bilgilerden yoksun olabilmektedir. Sonuçta, kendi çocuklarının da yoksulluk içinde büyüme riski artmakta ve bu bir kısır döngü halini almaktadır. Bu nedenle çocuk yoksulluğu acil önlem alınması gereken konular arasında yer almaktadır (Temiz, 2002, UNICEF, 2011).

\section{Kaynaklar}

Akça Ay, F. 2008. Temel Hemşirelik: Kavramlar, İlkeler, Uygulamalar. İstanbul Medikal Yayıncılık, 2. baskı, İstanbul, s. 47.

Aksan, G. 2012. Yoksulluk ve yoksulluk kültürünün toplumsal görünümleri. Selçuk Üniversitesi Sosyal Bilimler Enstitüsü Dergisi, 27, 9-19.

Alasya, E. 2012. 1-6 Yaş Grubu Çocuklarda Ev Kazası Görülme Siklĭg ve Annelerin Ev Kazaları ile İlgili Uygulamalarının Belirlenmesi. Yüksek Lisans Tezi, Yakın Doğu Üniversitesi.

Altundağ, S. 2005. Ev Kazalarına Yönelik Eğitiminin, Güvenlik Önlemleri Alınması ve Kaza Görülme Slklı̆̆ına Etkisi. Yüksek Lisans Tezi, Dokuz Eylül Üniversitesi

Aneshensel, C.S. \& Sucoff, C.A. 1996. The neighborhood context of adolescent mental health. Journal of Health and Social Behavior, 36, 293-310.

Anthony, E.K., King, B. \& Austin, M.J. 2011. Reducing child poverty by promoting child well-being: Identifying best practices in a time of great need. Children and Youth Services Review, 33, 1999-2009.

Arpacıoğlu, Ö. \& Yıldırım, M. 2011. Dünyada ve Türkiye'de yoksulluğun analizi. Niğde Üniversitesi İIBF Dergisi, 4(2), 60-76.

Ball J.W., Bindler, R.C. \& Cowen, K.J. 2010. Child Health Nursing: Partnering with Children\&Families. Pearson Education, $2^{\text {nd }}$ ed, s. 1391-1428.

Bayındır, N. 2010. Aile içinde yaşanan şiddete karşı çocuğun gösterdiği tepkiler. Mehmet Akif Ersoy Üniversitesi Sosyal Bilimler Enstitüsü Dergisi, 2(2), 1-9.

Begum, S.S., Deng, Q. \& Gustafsson, B. 2012. Economic growth and child poverty reduction in Bangladesh and China. Journal of Asian Economics, 23, 73-85.

Bisai, S., Ghosh, T. \& Bose, K. 2010. Prevalence of underweight, stunting and wasting among urban poor children aged 1- 5 years of West Bengal, India. International Journal of Current Research, 6, 39-44.

Bowen, N.K. \& Bowen, G.L. 1999. Effects of crime and violence in neighborhoods and school on the school behavior and performance of adolescents. Journal of Adolescent Research, 14, 319-342.

Blair, C., Berry, D., Mills-Koonce, R. \& Granger, D. 2013. Cumulative effects of early poverty on cortisol in young children: Moderation by autonomic nervous system activity. Psychoneuroendocrinology, 38, 26662675.

Cinar-Dede, N. 1999. 0-6 Yaş Çocuklarda Annenin Ev Kazalarına Yönelik Güvenlik Önlemlerini Tanılama Ölçeğinin Gelişstirilmesi ve Çocuktaki Kazaları Önlemede Annelere Verilen Eğitimin Etkisi. Doktora Tezi, İstanbul Üniversitesi. 
Cousins, L.H. 2013. Deservingness, children in poverty, and collective well being. Children and Youth Services Review, 35, 1252-1259.

Curtis, K.J., Voss, P.R. \& Long, D.D. 2012. Spatial variation in poverty-generating processes: Child poverty in the United States. Social Science Research, 41, 146-159.

Drake, B. \& Rank, M.R. 2009.The racial divide among American children in poverty: Reassessing the importance of neighborhood. Children and Youth Services Review, 31, 1264-1271.

Duman, Z., Ozdağ, Ş, Ozcan, A. 2003. Aile içi şiddetin çocuk üzerindeki etkisi konusunda hemşire öğrencilerin görüşleri. Atatürk Üniversitesi Hemşirelik Yüksekokulu Dergisi, 6(2), 50-56.

Durgun, Ö. 2011. Türkiye'de yoksulluk ve çocuk yoksulluğu üzerine bir inceleme. Bilgi Ekonomisi ve Yönetimi Dergisi, 6(1), 143-154.

Ersoy, M. 2006. Kentsel Alanlarda Yoksul Kesimin Sağlık Sorunları: Ankara ve Diyarbakır Kentlerinde Karşılaştırmalı Bir Araştırmanın Gösterdikleri. Kent ve Sağllk Seтроzyumu Bildiriler Kitabı, Bursa, s.3339.

Fajth, G., Engilbertsdóttir, S. \& Kurukulasuriya, S. 2012. From comparative to global social policy: Lessons for development practitioners from UNICEF's Global Study on Child Poverty and Disparities. Children and Youth Services Review, 34, 499-508.

Fotso, J.C., Madise, N., Baschieri, A., Cleland, J., Zulu, E., Mutua, M.K. \& Esendi, E. 2012. Child growth in urban deprived settings: Does household poverty status matter? At which stage of child development? Health \& Place, 18, 375-384.

Gornick, J.C. \& Jäntti, M. 2012. Child poverty in cross-national perspective: Lessons from the Luxembourg Income Study. Children and Youth Services Review, 34, 558-568.

Gorgun, S., Tiryaki, A. \& Topbas, M. 2010. Üniversite öğrencilerinde madde kullanma ve anne babaya bağlanma biçimleri. Anadolu Psikiyatri Dergisi, 11, 305-312.

Gürarslan-Baş, N. \& Karataş, B. 2013. Yoksulluğun 1-4 yaş grubu çocuklarda hastalanma sıklığı üzerine etkileri. Anadolu Hemşirelik ve Sağlık Bilimleri Dergisi, 16(3), 141-147.

Hackett, M., Melgar-Quiñonez, H. \& Álvarez, M.C. 2009. Household food insecurity associated with stunting and underweight among preschool children in Antioquia, Colombia. Rev Panam Salud Publica/Pan Am J Public Health, 25(6), 506-510.

Hannum, E., Liu J. \& Frongillo, E. 2014. Poverty, food insecurity and nutritional deprivation in rural China: Implications for children's literacy achievement. International Journal of Educational Development, 34, 90-97.

Hatun, Ş. 2002. Çocuk Hakları Sözleşmesinin 13. Yılında Yoksulluk ve Çocuklar Üzerine Etkileri. Türk Tabipleri Birliği Merkez Konseyi, Ankara, s. 7-29.

Hjern, A., Ringback ,G. \& Andersson. R. 2001. Socio-demographic risk factors for home-type injuries in Swedısh infants and toddlers. Acta Paediatrica, 90(1), 61-68.

Isanaka, S., Mora-Plazas, M., Lopez-Arana, S., Baylin, A. \& Villamor, E. 2007. Food insecurity is highly prevalent and predict underweight but not overweight in adults and school children from Bogota, Colombia. J Nutr, 137(12), 2747-2755.

Joo, M. 2013. Explaining heterogeneity in the child poverty rate among immigrant families: Differences by parental citizenship. Children and Youth Services, 35, 668-677.

Kabaş, T. 2009. Gelişsmekte Olan Ülkelerde Yoksulluğun Nedenleri ve Yoksullukla Mücadele Yolları. Doktora Tezi, Çukurova Üniversitesi. 
Kaya, Y. \& Şahin, N. 2013. Kadınlarda madde kullanımı ve hemşirenin rolü. Hemşirelikte Eğitim ve Araştırma Dergisi, 10(1), 3-7.

Koyun, A., Taşkın, L. \& Terzioğlu, F. 2011. Yaşam dönemlerine göre kadın sağlığı ve ruhsal işlevler: Hemşirelik yaklaşımlarının değerlendirilmesi. Psikiyatride Güncel Yaklaşımlar, 3(1), 67-99.

MEGEP. 2007. Mesleki Eğitim ve Öğretim Sisteminin Güçlendirilmesi Projesi. Çocuk Gelişim ve Eğitimi: Toplum ve Çocuk, T.C. Milli Eğitim Bakanlı̆̆ı, Ankara, s.20-22.

Özcebe, H. 2006. Çocuk Sağlığını Etkileyen Faktörler. Halk Sağlı̆̆ı Temel Bilgiler. Editörler: Çağatay Güler, Levent Akın, Hacettepe Üniversitesi Yayınları, Ankara, s. 330.

Phipps, S.A., Burton, P.S., Osberg, L.S. \& Lethbridge, L.N. 2006. Poverty and the extent of child obesity in Canada, Norway and the United States. Obesity Rewiews, 7(1), 5-12.

Sampson, R.J., Morenoff, J. \& Gannon-Rowley, T. 2002. Assessing neighborhood effects: Social processes and new directions in research. Annual Review of Sociology, 23, 443-478.

Sucaklı, M.H. 2003. Van Yöresinde Kadın ve Çocuğa Yönelik Aile İçi Şiddet. Uzmanlık Tezi, Yüzüncü Yıl Üniversitesi.

Taş, H.Y. \& Özcan, S. 2012. Türkiye'de ve Dünya'da yoksulluk üzerine bir araştırma. International Conference on Eurasian Economies, 423-430.

Taş̧̧ı, E., Atan, Ş., Durmaz, N., Erkuş, H. \& Sevil, Ü. 2005. Kız Meslek Lisesi öğrencilerinin madde kullanma durumları. Bağımlılık Dergisi, 6, 122-128.

Temiz, H.E. 2002. Dünyada kronik yoksulluk ve önleme stratejileri. Çalışma ve Toplum, 2, 61-100.

TNSA. 2008. Türkiye Nüfus ve Sağlık Araştırması. Hacettepe Üniversitesi Nüfus Etütleri Enstitüsü, 165-183.

Törüner, E.K. \& Büyükgönenç, L. 2012. Çocuk Sağlı̆̆ Temel Hemşirelik Yaklaşımları. Göktuğ Yayıncılık, Ankara.

Trani, J.F. \& Cannings, T.I. 2013. Child poverty in an emergency and conflict context: A multidimensional profile and an identification of the poorest children in Western Darfur. World Development, 48, 48-70.

Turan, T. \& Ceylan, S.S. 2007. 0-6 yaş grubu çocukları olan annelerin ev kazalarını önlemek için aldıkları güvenlik önlemlerinin aile özelliklerine ve son bir aydaki ev kazaları sıklığına göre değerlendirilmesi. Sağllk ve Toplum, 17(4), 52-58.

Turan, T., Altundağ-Dündar, S., Yorgancı, M. \& Yıldırım, Z. 2010. 0-6 yaş grubu çocuklarda ev kazalarının önlenmesi. Ulus Travma Acil Cerrahi Dergisi,16(6), 552-557.

Türker, K., Balc1, E., Batı, S., Hasçuhadar, M. \& Savaş, E. 2011. Ülkemizde Hepatit A enfeksiyonunun değişen epidemiyolojisi. Türk Mikrobiyol Cem Derg, 41(4), 143-148. UNICEF. 2005. The State of The World's Children: Childhood Under Threat. s.18.

UNICEF. 2011. Türkiye'de Çocukların Durumu Raporu: Yoksul Çocuklar. s.15-28.

UNICEF. 2012. Dünya Çocuklarının Durumu: Kentsel Bir Dünyada Çocuklar. Yönetici Özeti, 1-11.

Yılmaz, E. 2012. Yaşam Kalitesi Temelinde Toplumsal Şiddet, Göç ve Yoksulluğun İncelenmesi. Konya İl Sosyal Yardımlaşma ve Dayanışma Vakfı Başkanlığı Projesi, s. 25.

Zuberi, A. 2012. Neighborhood poverty and children's exposure to danger: Examining gender differences in impacts of the Moving to Opportunity experiment. Social Science Research, 41, 788-801. 